Marmara Üniversitesi Siyasal Bilimler Dergisi • Marmara University Journal of Political Science • Cilt 5, Özel Sayı, Nisan 20I7, ISSN 2147-6934, ss. 107-124 • DOI: xxxx

\title{
The Red-Bull Effect: Causes and Consequences of Overconfidence in Foreign Policy Decision Making
}

\author{
İmran DEMİR*
}

\begin{abstract}
Why do foreign policy decision makers take risk in situations that require prudence? Why do they escalate their commit to a failing course of action? This research examines the impact of overconfidence in foreign policy decision making. Building on extensive literature in social psychology, the premise of my argument is that successful past performance leads decision makers to develop overconfidence in their judgment, capacity and expectations, which bias their risk assessments. Based on this assumption, I develop a model that explains the causes and consequences of overconfidence in foreign policy decision making. In the model, past success persuades decision makers to overweight their skills and knowledge relative to what objective evidence warrants, which generates inordinate risk taking and exposes decision makers to sever failures. However, belief in success survives despite glaring setbacks, which convinces decision makers to escalate their commitment to a failing course of action. Nevertheless, there is a limit to decision makers' ability to engage in self-deception. Therefore, over the course of repeated failures, it is expected that the decision makers will make adjustments to correct overconfident reactions.
\end{abstract}

Keywords: Overconfidence, Past Success, Risk, Attribution Bias, Escalation of Commitment.

\section{Red Bull Etkisi: Dış Politika Karar Alma Süreçlerinde Aşırı Güvenin Neden ve Sonuçları}

\section{Öz}

Dış politika karar alıcıları neden temkinli olmayı gerektiren durumlarda risk almayı tercih ederler? Neden aynı karar alıcılar başarısızlıkla sonuçlanma olasılığı yüksek olan kararlarında ısrarcı davranırlar? Bu çalışma aşırı özgüven faktörünün dış politika karar alma surecine yaptığ̣ etkiyi incelemektedir. Çalışmamda, sosyal psikoloji literatüründeki yaygın yaklaşımlardan faydalanarak geçmişteki başarıların karar alıcılarda beceri ve bilgilerine aşırı güvenme yanılgısı yarattığını ve bu aşırı özgüvenin karar alıcıları riskli durumları değerlendirirken kapasitelerinde yanılgıya düşmelerine neden olduğunu savunmaktayım. Bu varsayımdan hareket ederek, dış politika karar alma süreçlerinde aşırı güvenin neden ve sonuçlarını gösteren bir model geliştirmekteyim. Model de geçmiş başarı karar

Assist. Prof., Marmara University, Faculty of Political Science, Department of International Relations, imran.demir@marmara.edu.tr 
alıcıları somut verilerle desteklenemeyecek üstün kapasiteye sahip olma yanılgısına ikna etmekte ve aynı karar alıcıların ciddi başarısızlıklarla sonuçlanabilecek risk alma eğilimini artırmaktadır. Olumsuzsuz sonuçların elde edilmesine rağmen, karalarını gözden geçirmek yerine, başarının kaçınılmaz olduğuna duyulan inanç, karar alıcıları kararlarında ısrarcı davranmaya sevk etmektedir. Ne var ki yanılgıda ısrarcı olmanın bir siniri olduğu varsayımından hareketle, karar alıcıların aşırı özgüvenle giriştikleri kararlarında düzeltmeye gitmeleri beklenmektedir.

Anahtar kelimeler: Aşırı Güven, Geçmiş Başarı, Risk, Yükleme Yanılgısı, Kararda Israr.

\section{Introduction}

Why do foreign policy decision makers take risk in situations that require prudence? Why do they escalate their commitment to policies that are not likely to produce intended outcomes? A reasonable explanation to these puzzles vary. Expected Utility Theory (EUT) assumes that decision makers are motivated by the desire to maximize their utility, and thus they choose the outcome with the most payoff and highest probability of occurrence (von Neuman and Morgenstern, 1944). This assumption, however, has been seriously challenged by the prospect theory. Developed by Kahneman and Tversky (1979; 1984), the theory posits that risk-taking behavior is conditioned by decision making context, which makes individuals risk averse in the domain of gains and risk seeking in the domain of losses. The application of this premise has produced a considerable literature in a wide variety of fields including international relations (Levy, 1992; McDermott, 1998; Taliaferro, 2004; Vis, 2011).

However, there are anomalies to this pattern. Findings from diverse fields show that when people are overconfident, they are more likely to demonstrate a propensity to risk taking that violates the risk-taking assumptions of the prospect theory (Odean, 1998; Hilary and Menzley, 2006; Hilton et al., 2011). Despite the prevalence of this bias in human judgment, scant attention has been devoted to the implications of overconfidence in foreign policy decision making. This research intends to fill this gap. Building on well-established findings in social psychology, I construct a model that predicts the causes and consequences of overconfidence in foreign policy decision making environments. The premise of my argument is that successful past performance generates attribution bias that produces and sustains overconfidence in judgment, capacity and expectations.

Analogues to the sensation that people experience following the consumption of an energy drink, overconfidence or what here is called "red bull effect" leads to a state of positive illusions, in which decision makers develop unrealistically positive self-evaluations, overrate their control over events, and overestimate the likelihood of experiencing positive outcomes. However, overconfidence does not make good basis for action. As overconfidence is a deviation from reality, overconfident decisions by definition are more likely to result in failure. 
Overconfidence that biases decision makers' risk perception is also expected to bias their reaction to feedback that contradicts their expectations. Therefore, it is argued that when overconfident decision makers receive warning signals indicating unfeasibility of their decisions, they are likely to show resistance to or bias new information in a self-serving manner. Biased information processing misleads them to escalate their commitment with the anticipation that future effort will produce desired outcomes.

The rest of this paper is organized as follows. In the next section, I discuss theoretical approaches to risk taking with an emphasis on prospect theory. The third section presents the theoretical foundations of the model I construct to explain the causes and consequences of overconfidence in foreign policy decision making. The fourth section devises the model. The study concludes with the implications of the argument and makes suggestions for the future research.

\section{Primary Approaches to Risk Taking}

What is risk and what motivates risk taking behavior? There are unfortunately little systematic attempts at understanding the nature of risk in international relations and foreign policy studies (Jarvis and Griffiths, 2007). Despite being critically relevant to a domain governed by anarchy and uncertainty, scholarly attention has not been equally attentive. Much of the field's understanding of the concept of risk is shaped by definitions imported from the field of economics (Vertzberger, 1995). This has primarily been a natural consequence of the prevalence of rational choice approach in international relations studies (O'neill, 2001). In these studies, risk is treated as a function of decision choices over outcomes where decision makers have perfect knowledge of all possible occurrences with associated probability distributions (Vertzberger, 1995). Risk, therefore, is defined as the probability that a policy will not achieve its goals with potential adverse effects (Lamborn, 1985).

However, a probabilistic approach to risk is meaningful only if probabilities of different events are known in advance. This is not certainly the case in international relations and foreign policy domains where uncertainty is pervasive as a result of incomplete, ambiguous and ill-structured nature of information on the basis of which states and their representatives have to devise their policies (Vertzberger, 2008).

Vertzberger (1995) offers a definition of risk in international relations that subsumes uncertainty. Incorporating uncertainty into the definition of risk also allows accounting for the risk perception of decision makers. This gives a more realistic notion of risk that is more applicable to the illstructured nature of problems that decision makers face in foreign policy decision making environments. Based on these considerations, Vertzberger (1995, p.351) constructs a definition where "risk is defined as the likelihood of the materialization of validly predictable direct and indirect consequences with potentially adverse values, arising from events, self-behavior, environmental constraints, or the reaction of an opponent or third party." 
These differences in conception of risk also find their way into explanations of motivation for risk taking behavior. The mainstream international relations and foreign policy research rely on rational choice explanations of risk taking behavior. Typically, in these studies risk taking is modeled as a function of costs and benefits. From rational choice or expected utility perspective, individual choices reflect their preferences for options on which they are prepared to act. These choices also reflect the degree of belief in the success probability of alternative courses of action. Thus, individuals choose outcomes that they think are most likely to take place. These choices are also presumed to maximize utility as long as they satisfy certain axioms (See Stigler, 1950; Arrow, 1951; Edwards, 1954; Becker and McClintock, 1967; Karni, 2014).

Expected utility theory (EUT) for the most part is considered as a normative theory of choice without much concern for describing or explaining decision processes. The purpose of the theory is to prescribe how people ought to behave to optimize their preferences rather than how these preferences are formed (Friedman, 1953; McDermott, 1998). Despite the treatment of rational choice as the metatheory of decision making, it has been shown that people systematically behave in ways that violate the assumptions of the utility theory (For criticisms of utility theory see Tversky, 1975; Fischhoff et al., 1981; Schoemaker, 1982; Karni, 2014). For instance, scholars as early as Simon (1955) have observed the prevalence of satisficing behavior over utility maximization among majority of people.

Among many of its weaknesses and flows, it has been severely criticized for failing to account for limitations on mental capacity of people to process information, which prevents them to act in consistent with the prescriptions of the theory (See Schoemaker, 1982; Fishburn, 1988). To cite just a few of these problems, Markowitz (1952) challenged the wiggly utility curve of Freidman and Savage (1948). Mosteller and Nogee (1951) showed that individuals repeatedly violated the axiom of definite preferences. Ellsberg (1961), focusing on the probability dimension showed that people disliked ambiguity and displayed a preference for certainty. Tversky (1975) observed violation of transitivity axiom. The Allasis and Ellsberg's (1961) paradox showed the violations of independence or sure thing axiom, which holds that if two lotteries have an identical probability and payoff branch, the levels of this payoff and probability should not affect people's choice between the lotteries. Kahneman and Tversky (1979) generalizing from Allias (1979) paradox observed invariance of preferences between certainty and risk. Bar-Hillel (1973) found that people tend to overestimate the probability of conjunctive events and underestimate the probability of disjunctive events.

Each of these violations stems either from demanding too much from the individual or insensitivity to the context of decision making. People do not "follow the calculus of chance or the principles of statistics" or acquire and process information the way that a computer does (Kahneman and Tversky 1982, p.48). They do not for instance assign numbers to alternative courses of actions and use calculators to make probabilistic assessments. Human judgment operates as a measurement device to assess subjective probability associated with alternative options. This leaves them vulnerable to various heuristics and biases that result in suboptimal 
outcomes (Tversky and Kahneman, 1974; Nisbett and Ross, 1980; Hoagarth and Makridakis, 1982; Einhorn and Hogarth, 1986; Gilovich, Griffin and Kahneman, 2002).

These mounting violations have raised questions over the utility of following the prescriptions of a model that did not have empirical validity. As Tversky (1975) puts it "if people are systematically violating some principles it would be natural to revise those principles not the way people decide on their preferences."

These systematic violations have been formalized by Kahneman and Tversky (1979) under the prospect theory to descriptively show behavioral patterns people follow when dealing with risk. Prospect theory (PT) in one statement is an explanation of reference dependent and loss aversive risk orientation of human behavior. It is a decision-making approach that deals with how individuals behave under conditions of risk (Kahneman, 1979; Tversky, 1981).

Unlike rational choice approach, prospect theory is a psychophysical approach to decision making, where objective stimuli or quantities are meaningful only through subjective experience (Heukelom, 2007). This means that people do not make choices from a fixed asset level as assumed by utility theory but rather from a subjective position where they code outcomes as gain, loss, or neutral. Thus, prospect theory places a special emphasis on the context of decisionmaking (McDermott, 1998). The context dependent approach of PT identifies two conditions relevant to decision making environment: reference point and framing effect. These two factors jointly determine the domain (of gain or loss) under which the decision makers operate.

Reference point is by far the most important conceptual component of the theory. Without the notion of the reference point, a discussion of losses and gains, risk taking, and risk aversion is pretty much meaningless. In non-technical language, reference point is a benchmark relative to which a situation is appraised. When faced with a decision-making situation, individuals assess the situation in relation to a reference point, which conditions their subsequent reaction (Kahneman, 1979; 1984). If the situation is an improvement relative to the reference point, then individuals code the situation as a gain. However, if the situation involves a loss, individuals treat the condition as a loss situation, which puts them in the domain of losses. The formulation of decisions relative to some reference points leaves reference point susceptible to framing effect. Framing is problem description or the presentation of the glass half full or half empty (Tversky, 1981; Bazerman 1984; Neale and Bazerman, 1985). It indicates that preferences of people are subject to shifts depending on whether an issue is formulated as a gain or a loss.

In purely expected utility considerations, how an option is perceived should not lead to preference reversals or shifts in choices (i.e., intransitivity). However, the presentation format of the decision problem has important consequences on subsequent choices (e.g., Redelmeir and Tversky, 1992; Kam and Simas, 2010). To be more specific, consider the illustration of the presentation of the success probability of a medical treatment. Framing the treatment with $50 \%$ success rate and alternatively $50 \%$ failure will induce different responses. 
If reference point is the organizing concept of the prospect theory, loss aversion is the principle assumption of the theory. It is to prospect theory what utility maximization is to EUT with of course entirely opposite implications. Loss aversive behavior is primarily conditioned by the endowment effect (Thaler, 1980), which suggests that people value goods in their possession more than goods yet to be acquired (Thaler, 1980; Knetsch and Sinden, 1984; Knetsch, 1989; Kahneman, Knetsch and Thaler, 1991). Under endowment effect, gratification of acquiring a new good is always less than the gratification of protecting a good already in one's possession. In addition, once something is acquired it does not take very long to internalize that gain and establish a status quo over it. This, however, is not the case for losses. It takes more time for individuals to make peace with their losses (Tversky, 1991; see also Knetsch and Sinden, 1987; Knetsch, 1989; Sen and Johnson, 1997).

Aversion to losses has two fundamental consequences in terms of how people treat losses and gains, and the corresponding risk taking behavior. In the first place, people are more sensitive to losses than to gains, which implies that losses hurt more than equal gains satisfy. Indeed, losses are so painful that people hate to lose more than the satisfaction they draw from equal gains. For instance, losing \$20 and making \$20 do not have the same cognitive impact.

Prospect theory's prediction that preferences are heavily biased towards loss aversion has important consequences for risk orientation leading to what Kahneman and Tversky (1979; Tversky, 1981) label as reflection effect. This effect generates risk aversion when people are facing positive prospects but fosters risk seeking behavior when they face negative prospects.

Aversion to risk in the domain of gains is predicted by prospect theory's certainty effect, which induces people to prefer choices close to certain over choices that are merely probable (Tversky, 1981). By contrast sensitivity to losses makes people more aggressive and more risk acceptant to recover their losses. Therefore, loss aversion has been offered as a viable explanation for people's tendency to escalate commitment over sunk costs to recoup their past losses (Bazerman et al., 1984; Arkes and Blumer, 1985; Gerland, 1990; Whyte, 1993; Schaubroeck and Davis, 1994; Taliafero, 2004;).

To summarize then, prospect theory assumes people to be loss averse, and based on this assumption predicts them to be risk averse for gains and risk seeking for losses. However, the empirical validity of this claim has not been quite robust. Systematic violations of the prospect theory predictions have been observed in investigations conducted by Frisch (1993) and Schnider (1992) and Schnider and Lopes (1986) among others.

Thaler and Johnson (1990) argue that these deviations might be due to the static nature of the original formulation of the theory. Although prospect theory heavily emphasizes reference point to determine the direction of risk taking behavior as summarized earlier, it is strictly deduced from a single period model of decision making without much consideration for how individuals may react or how preferences may shift in situations involving sequential decisions or prior outcomes. 
Therefore, Thaler and Johnson (1990) maintain that the deviations from the assumptions of the prospect theory can be explained through the knowledge of outcomes that have preceded current choices. Adopting assumptions from hedonic editing hypothesis, which predicts individual choices according to the degree of satisfaction that they draw form particular outcomes, they find prior outcomes to have strong framing effects on the reference point. Specifically, they show that individuals using a cognitive procedure called mental accounting integrate subsequent losses with a prior gain, which induce more risk seeking behavior. They explain this observation to which they call 'house money effect', by relying on a similar behavior demonstrated by gamblers ahead. Thus, they conclude that initial gains may afford individuals to be more risk acceptant after prior gains, which mitigate the influence of loss aversion and facilitate risk taking. Calling this the house money effect, they argue that individuals experiencing initial gains develop a tolerance to smaller losses, which are treated as reductions in gains rather than reductions in initial asset positions or endowments.

While Thaler and Johnson's (1990) reformulation of risk aversion based on sequential decision making can be considered as an improvement over the single period risk averse prediction of prospect theory for showing that risk taking propensity is subject to shifts depending on how prior outcomes are framed, their working assumption is still based on the assumption that individuals are predominantly risk averse. Note that under the house money effect, the upper bound of losses is fixed, which suggests that subsequent losses cannot be larger than the original gain in order for the risk-taking behavior to be observed. In other words, the degree of risk seeking behavior can only be as large as the amount of prior gain. Otherwise, risk acceptant behavior may not be observed. Thus, under house money effect people find it reasonable or tolerable to lose up to the value of a previous gain.

\section{Causes and Consequences of Overconfidence in Decision Making}

Alternative explanations of risk seeking behavior, which rely on overconfidence, exist. Although in these explanations risk-taking is still influenced from how prior outcomes are framed, this behavior is more aligned with risk-seeking tendency in the domain of gain.

A good place to explore the implications of overconfidence for risk propensity is to discuss what it is. Overconfidence is a problem of judgment where individuals hold mistaken valuations that they believe in too strongly (Daniel and Hirschfield, 2015). It is the difference between the reality and the perception of reality (Russo and Shoemaker, 1992).

The literature on the topic has identified different manifestations of overconfidence. One line of research treats overconfidence as a problem of caliberation or overestimation of knowledge. Miscaliberated people overestimate the precision of their knowledge and the accuracy of their forecasts (Fischhoff et al., 1977; Lichenstein and Fischhoff 1977; Lichtenstein et al., 1982; Russo, 1992; Moore and Healy, 2008). Another form of overconfidence manifests itself in terms of overestimation or illusion of control over outcomes due to heavy reliance on one's skills (Langer, 
1975; Heath and Tversky, 1991; Krueger and Dickson, 1994; Camerer and Lovallo, 1999). Individuals with this bias fail to make accurate predictions about outcomes by exaggerating their control over largely uncontrollable events. Overconfidence also displays itself in the form of unrealistic optimism. People with overconfidence overestimate the chances of experiencing positive outcomes (Weinstein, 1980; March and Saphira, 1987; Taylor and Brown, 1988; Baumasister, 1989; Krueger and Dunning, 1994; Lovella, 2003).

Self-serving attributions that people make are found to be an important determinant of overconfidence (Gervais and Odean, 2001; Malmendier and Tate, 2005; 2008; Hillary, 2006; Libby and Rennekamp, 2012;). Attribution theories of behavior postulate that when individuals make causal explanations for outcomes of their actions, they demonstrate a marked tendency to attribute positive outcomes to personal skills and competence and attribute negative outcomes to external factors beyond control (Bradly 1978; Taylor, 1988; Fiske and Taylor, 1991; Shepherd, Malone and Sweeny, 2008;). This results in people's inclination to "overweight their success and underweight their failures and they overweight success more than failure" (Gervais, 2001; p.4). Positive performance perception created by positive prior outcomes lead to excessive confidence in self evaluative judgments. Success convinces decision makers to believe that they are highly competent with a capacity to control the odds and increases the optimism for positive outcomes.

Gervais and Odean (2001) shows the relation between attribution bias and overconfidence in a multi-period model of overconfident traders, whose learning bias achieved from prior trading outcomes persuade them to overweight the probability of success. Hillary and Menzely (2006) find that financial analysts with prior experience of success display more confidence in their ability to predict future earnings. Similar findings are reported by Libby and Rennekamp (2012), who find managers with prior positive performance to develop self-serving attributions which increased their confidence improved future performance.

Although overconfidence biases people's judgment of capabilities for achievement of specific goals and their expectations for positive outcomes, it does not make good basis for action. Plethora of research shows that overconfidence increases risk taking propensity of individuals especially when they are led to believe that the outcome of an action depends on their skills rather than chance (Weinstein, 1980; Vlek and Stallen, 1981; Heath, 1991; Camerer, 1999). From an overconfident decision maker's perspective risk is controllable through personal wisdom and skills (Donaldson and Lorsch, 1983; Camerer, 1999), which increases their optimism for positive outcomes (Krueger and Dickson, 1994).

When overconfident people make risky choices, they do not necessarily think they are overconfident or the choices they make involve risk. Instead, their attribution bias framed by their successful past performance shadows their reasoning and persuades them to rely too heavily on their private information. This convinces them to think that the choices they make are within the reach. As a result, they act on and commit recourses to their highly confident predictions without taking into account the possibility of experiencing adverse outcomes or taking any precautions to protect 
them against unanticipated setbacks (Dunning et al., 1990). This unreasonable attitude towards risk, therefore, leaves them vulnerable to severe failures. Overconfidence has been found to be an important determinant of excessive trading volumes (Odean, 1998; Barber and Odean, 2000; Daniel and Hirschleifer, 2015), overinvestment decisions and poor acquisitions (Malmendier, 2005; 2008; Billet and Qian ,2008), unsuccessful venture formations (Simon et al., 2000), failed new product introductions (Simon and Houghton, 2003) and even lost wars (Johnson, 2004).

Overconfidence also has been found to considerably bias decision makers' reaction to negative feedback relevant to their decisions (Boulding et al., 1997; Schmidt and Calantone, 1998; Schmidt and Calantone, 2002; Lovallo, 2003; Juliusson, 2006; Keil et al., 2007; Jensen et al., 2011; Meyer, 2014;). Research on escalation of commitment (Staw, 1976) shows that overconfident decision makers are more likely to evaluate feedback in a biased manner which feeds their tendency to maintain belief in success, and thus, persist in a course of action with the anticipation that additional effort is likely to produce anticipated outcomes.

Two possible explanations can be identified for the inclination of overconfident decision makers to escalation of commitment. In the first place, overwhelmingly focusing on aspects of the decision that feeds their expectation for success misleads them to take into account factors that are likely to defy their capacity as well as their expectations (Schmidt, 1998; Lovallo, 2003; Juliusson, 2006; Jensen et al., 2011; Meyer, 2014). Decision makers also are likely to overestimate their control over the outcomes of their decisions and may assume that they are more likely to succeed despite feedback indicating otherwise (Langer, 1975; Duhaime and Schwenk, 1985; Boulding et al., 1997; Schmidt, 2002; Keil et al., 2007).

Thus, when negative information arrives, overconfident decision makers are expected to display a number of predictable information biasing patterns. One prevalent information biasing mechanism grounded in cognitive dissonance is confirmation bias where individuals seek for information that are consistent with their preexisting beliefs. Contradictory information is discounted to avoid dissonance (for overviews, see Frey, 1986; Hart et al., 2009). Another robust information biasing error that may result from overconfidence is the tendency to overvalue information consistent with their preferred alternative more than information that contradicts their expectations, which convinces them to maintain suboptimal preferences (Lord, Ross and Lepper, 1979; Greitemeyer Schulz-Hardt, 2003; Russo, Carlson and Meloy, 2006).

Excessive confidence in ability to control outcomes also persuades decision makers to engage in attribution bias relegating failure to outside factors beyond control (Hunning, 2004). Overly optimistic self-assessment to think that they possess the required skills to salvage the situation and belief in chances of success biases the interpretation of negative feedback and information at hand and convince decision makers to simply "transform losses" into the near feature (Gilovich, 1983). Biased evaluations and inflated expectations in turn urge them to engage in escalation on inconclusive commitments. 


\section{The Red Bull Effect: Causes and Consequences of Overconfidence in Foreign Policy Decision Making}

What are the implications of this argument for foreign policy decision making environments? Based on the preceding discussion it is argued that when foreign policy decision makers are overconfident, they are more likely to demonstrate behavioral patterns that deviate from the risk averse predictions of prospect theory.

Before model specification, certain qualifications are warranted. The first qualification is that there are limitations in human's ability to process information. In the absence of precise tools and devices to resolve uncertainty and predict future, decision makers rely on various simplifying devices and cognitive heuristics that make decision makers' judgment susceptible to various biases and errors (Einhorn and Hogarth, 1986). This problem is likely to be more prevalent in foreign policy decision making environments in which the relevant information to the decision making is often scarce, unreliable and ambiguous, the feedback is often slow and incomplete, and misperception is pervasive (Vertzberger, 1995; 2008; Hermann, 2012).

A less general assumption is that decision making context involves sequential decision making, where current decisions are influenced from past outcomes in addition to current circumstances and future projections or considerations (Vertzberger, 1995; Hermann, 2012). Thus, the model specified below is multi-period with feedback loops between the outcomes of the past decisions and subsequent risky choices. In the model, decision makers' response go through a process of overreaction and auto-corrections following the realization of inefficient deviations. Thus, overconfidence is not constant but a time-varying property displaying variations as a result of feedbacks from the success and failure of past performances (Gervais, 2001).

Formulation of overconfidence as a time varying property allows for decision makers to observe how well they perform and based on these observations determine whether to persist with or withdraw from a course of action. At the beginning of each period, decision makers, who are assumed to be highly competent, as a natural consequence of the requirements of the position they occupy, make choices based on the knowledge of the outcomes, which have preceded current choices. Each period ends in success or failure. Thus, at the end of each period the decision maker has the opportunity to evaluate the outcome as confirmation or disconfirmation of their predictions. The magnitude of success or failure of these outcomes condition the decision makers' attitude towards risk.

The model begins with an event in the decision-making environment in the form of an opportunity and threat to fundamental foreign policy values and interests as perceived by the primary decision makers or their representatives (Hermann, 2012). Early losses are expected to create negativity bias under which the psychological tendency to abate the negative impact of an outcome urges the removal of aversive stimulus condition (Skinner, 1974; Taylor, 1991). This sensitivity makes people less tolerant to further losses creating a mindset analogous to the implications of the aphorism "bitten once, shy twice" (Thaler and Johnson, 1990) who use negative 
hot hand metaphor for this situation. Thus, it is predicted that early negative performance is likely to abort the sequence.

Successful performance, on the other hand, is expected to create attribution bias. It is expected that when decision makers receive signals confirming their position they are more likely ascribe these signals to their competence and personal skills. Positive outcomes are recorded as a confirmation of competence, which convinces decision makers to think highly of their abilities. This rises their confidence, inciting a behavioral pattern consistent with the red-bull effect. Updating their belief too fast to the information gathered from the feedback of their prior decisions increases confidence in their abilities which emboldens them to react in the same way to similar past events. In addition, it is expected that decision makers are more likely to use such outcomes as diagnostic cues to resolve uncertainty over the outcomes of similar decision problems. Practically such events are used as representative analogies eliciting pseudo-certainty effect whereby a potential outcome that is actually uncertain is weighted as if it is certain. Therefore, it is assumed that when decision makers receive signals confirming their position they are more likely to develop overconfidence.

Along these lines, overconfidence is modeled as an inflated sense of confidence in one's judgment, capacity and expectations. Overconfident decision makers overestimate the precision of their knowledge than it really is. This tendency undermines their ability to accurately predict forecasting error. Overconfidence at the same time convinces decision makers to have unrealistically positive self-evaluations (Greenwald, 1980). They not only consider to have better ability relative to their peers but they also see themselves better than how others see them (Taylor, 1988). Too much confidence in their capacity and judgment encourage them to establish their reference point around an expectation or performance level.

Although success makes decision makers overconfident, overconfidence does not make people more successful. Indeed, when decision makers are overconfident, they are more likely to demonstrate a propensity to risk taking, which is predicted to result in failure. However, when the new information disconfirming their expectation for success arrives, it is expected that decision makers' prior beliefs and optimistic expectations in success will bias their evaluation of the new information. They are expected to demonstrate a tendency to underweight information contradicting their beliefs, overweight confirming information and assimilate ambiguous and mixed information to fit their expectations. The tendency to bias information is likely to result in escalation of commitment over a failing course of action.

Although it may take more than one failure for decision makers to align their beliefs with reality, the model allows decision makers to learn from their failures and develop more realistic assessment of their true potential. This suggests that overconfidence will not last forever. However, how fast decision makers' overconfidence abate will depend on the frequency, speed, and clarity of the feedback they receive. Realization of one's true potential when the feedback is frequent, immediate, and clear is faster. Infrequent, delayed, and ambiguous feedback, on the other hand, 
will slow realization. Thus, it may take a while for the decision maker to come to their senses and realize the futility of persisting on a failing course of action.

\section{Conclusion}

The current work assembled a theoretical framework from various cognitive and behavioral explanations to predict the causes and consequences of overconfidence in foreign policy decision making environments. In the model, satisfactory prior performance outcome generates attribution bias, which leads to overconfidence in judgment, capacity and expectations. Relying too much on their private information increase decision makers' propensity to risk taking that is more likely to produce adverse outcomes. It is reasonable to expect people to withdraw from a commitment when they find out that their decisions are not likely to result in anticipated outcomes. However, this is not what overconfident decision makers do. When negative information arrives, overconfident decision makers are more likely down play negative information because of their certainty in the appropriateness of their choices. They are more likely to downplay contradictory information, overweight information that fits their expectations and assimilate mixed and ambiguous signals and/or interpret the new information in a self-serving manner.

This study makes important contributions to the psychological study of foreign policy decision making. It offers a model that deviates from conventional explanations of risk taking. The study also offers insights for understanding decision makers' tendency to persist in unproductive courses of action that may result in disaster. As such the model developed here can be of interest to scholars who study cause and consequences of risk taking as well as to those scholars who try to understand how biases and beliefs influence and shape the preferences of decision makers.

This study, however, readily acknowledges its inherent limitations. It lacks empirical foundations. Appropriate research designs and operational measures for the concepts should be constructed to allow for empirical investigation of the validity of the arguments advanced here. Case study method can be a good avenue to examine the implications of the framework. Future research can examine can apply the assumptions developed here to a wide variety of cases including but not limited to US invasion of Vietnam in late 60s, Iraq and Afghanistan in 2000s, as well as Soviet Union's invasion of Afghanistan. Turkish foreign policy towards Syria after the outbreak of violence in Syria following the protest movements in the Arab World can be another case where the contention of this framework can be applied. 


\section{References}

Allais, Maurice. (1979). “The So-called Allais Paradox and Rational Decisions under Uncertainty." In Expected Utility Hypotheses and the Allais Paradox. eds. Maurice Allais and Ole Hagen. Dordrecht: Reidel.

Arrow, Kenneth J. (1951) "Alternative Approaches to the theory of Choice in Risk taking situations" Econometrica. 19 (4): 4004-437.

Bar-Hillel, Maya. (1973) “On the Subjective Probability of Compound Events." Organizational Behavior and Human Performance 9 (3): 396-406.

Barber, Brad M., and Terrance Odean. 2000. "Trading is Hazardous to Your Wealth: The Common Stock Investment Performance of Individual Investors." Journal of Finance 55(2): 773-806.

Baumeister, Roy F. (1989) “The Optimal Margin of Illusion,” Journal of Social and Clinical Psychology 8 (2): 176-189.

Bazerman, Max H. Toni Guiliano, and Allen Appelman. 1984. "Escalation of Commitment in Individual and Group Decision Making." Organizational Behavior and Human Performance 33: 141-152.

Bazerman, Max H. (1984) “The Relevance of Kahneman and Tversky’s Concept of Framing to Organizational Behavior." Journal of Management 10 (3), 333-343

Becker, Gordon M., and McClintock, Charles C. (1967) "Value: Behavioral Decision Theory." Annual Review of Psychology 18 (1): 239-68.

Billet Mathew T., and Yimin Qian. (2008) "Are Overconfident CEOs Born or Made? Evidence of Self Attribution Bias from Frequent Acquirers." Management Science 54 (6): 1037-1051.

Biyalogorsky, Eyal, William Boulding, and Richard Staelin. (2006) "Stuck in the Past: Why Managers persist with new product failures." Journal of Marketing 70: 108-121.

Boulding, William, Ruskin Morgan, and Richard Staelin. (1997) "Pulling the Plug to Stop the New Product Drain." Journal of Marketing Research 34:164-176.

Bradley, Gifford Weary. (1978) "Self-Serving Biases in the Attribution Process: A Reexamination of the Fact or Fiction Question." Journal of Personality and Social Psychology 3 (1): 56-71.

Brockner, Joel. (1992) "The Escalation of Commitment to A Failing Course of Action: Toward Theoretical progress." Academy of Management Review 17 (1): 39-61.

Camerer, Colin, and Dan Lovallo. (1999) “Overconfidence and Excess Entry: An Experimental Approach.” American Economic Review 89 (1): 306-318.

Daniel, Kent, and David Hirshleifer. (2015) "Overconfident Investors, Predictable Returns, and Excessive Trading." Journal of Economic Perspective 29 (4): 61-88.

Donaldson, Gordon, and J. W. Lorsch. (1983) Decision Making at the Top: The Shaping of Strategic Direction. New York: Basic Books, 1983.

Duhaime, Irene M., and Charles R. Schwenk. (1985) Conjectures on Cognitive Simplification in Acquisition and Divestment Decision Making." Academy of Management Review 10 (2): 287-295.

Dunning, David, Dale Griffin, James D. Milojkovic, and Lee Ross. (1990) “The Overconfidence Effect in Social Prediction." Journal of Personality and Social Psychology 58 (4): 568-581.

Edwards, Ward. (1954) “The Theory of Decision Making." Psychological Bulletin 51 (4): 380-417.

Einhorn, Hillel J., and Robin M. Hogarth. (1986) "Decision Making under Ambiguity." Journal of Business 59 (4): 225-250.

Ellsberg, Daniel. (1961) “Risk. Ambiguity, and the Savage Axioms." Quarterly Journal of Economics 75 (4): 643-669. 
Fischhoff, Baruch, Paul Slovic, and Sarah Lichtenstein. (1977) "Knowing with Certainty: The Appropriateness of Extreme Confidence." Journal of Experimental Psychology 3 (4): 552-564.

Fischhoff, Baruch, and Bernard Goitein, and Zur Shapira. (1981) "Subjective Expected Utility: A Model of Decision-Making." Journal of The American Soceity for Information Science September: 391-399.

Fishburn, Peter C. (1988) “Expected Utility: An Anniversary and a New Era." Journal of Risk and Uncertainty 1: 267-283.

Frisch, Frisch. (1993) "Reasons for Framing Effects." Organizational Behavior and Human Decision Processes 54 (3): 399-429.

Fiske, S., and S. Taylor, (1991), Social Cognition (2nd ed.), McGraw-Hill, New York.

Frey, Dieter. (1982) "Different Levels of Cognitive Dissonance, Information Seeking, and Information Avoidance." Journal of Personality and Social Psychology 43 (6): 1175-1183.

Friedman, Milton, and Leonard J. Savage. (1948) "Utility Analysis of Choices Involving Risk." Journal of Political Economy 56 (4): 279-304.

Garland, Howard. (1990) "Throwing Good Money after Bad: The Effect of Sunk Costs on the Decision to Escalate Commitment to an ongoing Project." Journal of Applied Psychology 75, 728-731.

Gervais, Simeon, and Terrance Odean. (2001) "Learning to Be Overconfident." The Review of Financial Studies 14 (1): 1-27.

Gilovich, Thomas, Griffin, Daniel, and Kahneman, Daniel. (2002) Heuristics and Biases: The Psychology of Intuitive Judgment New York: Cambridge University Press.

Gilovich, Thomas. (1983) "Biased Evaluation and Persistence in Gambling." Journal of Personality and Social Psychology 44 (6): 1110-1126.

Greenwald, Anthony G. (1980) The Totalitarian Ego: Fabrication and Rveison of Personal History. American Psychologist 35(7): 603-618.

Greitemeyer, Tobias, and Stefan Schulz-Hardt. (2003) "Preference-Consistent Evaluation of Information in the Hidden Profile Paradigm: Beyond Group-Level Explanations for the Dominance of Shared Information in Group Decisions." Journal of Personality and Social Psychology 84 (2): 322-339.

Hart, William, Dolores Albarracin, Alice H. Eagly, Inge Brechan, Mathew J. Lindberg, and Lisa Merrill. (2009), "Feeling Validated Versus Being Correct: A Metaanalysis Of Selective Exposure to Information." Psychological Bulletin 135 (4): 555-588.

Heath, Chip, and Amos Tversky. (1991). "Preference and Belief: Ambiguity and Competence in Choice under Uncertainty." Journal of Risk and Uncertainty 4: 5-28.

Hermann, Charles F. (2012). "What We do When Things Go Wrong." In When Things Go Wrong: Foreign Policy Decision Making Under Adverse Feedback. ed. Charles F. Hermann. New York: Routlage.

Hillary, Gilles, and Lior Menzly. (2006). "Does Past Success Lead Analysts to Become Overconfident." Management Science 52 (4): 489-500.

Hogarth, Robin M., and Spyros Makridakis. (1981). “Forecasting and Planning: An Evaluation." Management Science 27 (2): 115-138.

Hunning, Tobias M; Neal F. Thomson. (2014). “The Impact of Performance Attributions on Escalation of Commitment." Journal of Organizational Culture, Communications and Conflict 18 (1): 115-122.

Jarvis, Darryl S.L., and Martin Griffiths. (2007) "Learning to Fly: The Evolution of Political Risk Analysis." Global Society 21 (1): 5-21.

Jensen, J. M., Conlon, D. E., Humphrey, S. E., and Moon, H. (2011) "The Consequences of Completion: How Level of Completion Influences Information Concealment by Decision Makers." Journal of Applied Social Psychology 41(2), 401-428. 
Johnson, Dominic D. P. Overconfidence and War: The Havoc and Glory of Positive Illusions. Cambridge, Massachusetts: Harvard University Press.

Juliusson, Ásgeir. (2006) “Optimism as Modifier of Escalation of Commitment.” Scandinavian Journal of Psychology 47: 345-348

Kahneman, Daniel, and Amos Tversky. (1984) “Choices, Values, and Frames." American Psychologist 39: 341-350.

Kahneman, Daniel, and Amos Tversky. (1982) "Judgement under Uncertainty: Heuristics and Biases." In Judgment under Uncertainty: Heuristics and Biases, eds., Daniel Kahneman, Paul Slovic, and Amos Tversky. New York: Cambridge University Press.

Kahneman, Daniel, and Amos Tversky. (1979) "Prospect Theory: An Analysis of Decisions under Risk." Econometrica 47: 263-291.

Kam, Cindy D., and Elizabeth N. Simas. (2010) “Risk Orientations and Policy Frames.” Journal of Politics 72 (2): 381-396.

Karni, Edi. (2014) Axiomatic Foundations of expected utility theory in the Handbook of Economics of Risk and Uncertainty. In: Mark J. Machina, W. Kip Viscusi, editors, Handbook of the Economics of Risk and Uncertainty. Vol 1, Oxford: North Holland.

Keil, Mark, Gordon Depledge, and Arun Rai. (2007) "Escalation: The Role of Problem Recognition and Cognitive Bias.” Decision Sciences 28 (3): 391-421.

Knetsch, J. L., and J.A. Sinden. (1984) Willingness to Pay and Compensation Demanded: Experimental Evidence of an Unexpected Disparity in Measures of Value." Quarterly Journal of Economics 99: 507521.

Knetsch, Jack L. (1989). The Endowment Effect and Evidence of Nonreversible Indifference Curves." American Economic Review 79: 1277-1284.

Knetsch, Jack L., and J. A. Sinden. (1987) The Persistence of Evaluation Disparities." Quarterly Journal of Economics 102: 691-695.

Krueger, Justin, and David Dunning. (1994) "Unskilled and Unaware of It: How Difficulties in Recognizing One's Own Incompetence Lead to Inflated Self-Assessments." Journal of Personality and Social Psychology 77 (6): 1121-1134.

Krueger, Norris, and Peter R. Dickson. (1994) How Believing in Ourselves Increases Risk Taking: Perceived Self-efficacy and Opportunity Recognition. Decision Sciences 23: 385-401.

Lamborn, Alan C. (1985) "Risk and Foreign Policy Choices." International Studies Quarterly 29 (4): 385-410.

Langer, Ellen J., and Jane Roth. (1975) "Heads I win, Tails It's Chance: The Illusion of Control as a Function of the Sequence of Outcomes in a Purely Chance Task." Journal of Personality and Social Psychology 32: 951-955.

Langer, Ellen. (1975) “The Illusion of Control.” Journal of Personality and Social Psychology 32 (2): 311-328.

Levy, Jack S. (1992) "Prospect Theory and International Relations: Theoretical Applications Analytical Problems." Political Psychology 13:283-310

Libby, Robert and Kristina Rennekamp. (2012) "Self-Serving Attribution Bias, Overconfidence, and the Issuance of Management Forecasts." Journal of Accounting Research 50 (1): 197-231.

Lichtenstein, Sarah, and Baruch Fischhoff. (1977) "Do Those Who Know More Also Know More about How Much They Know?” Organizational Behavior and Human Performance 20 (2): 159-183.

Lichtenstein, Sarah, Baruch Fischhoff, and Lawrence D. Phillips. (1982) Calibration of Subjective Probabilities: The State of the Art up to 1980. In Judgment under Uncertainty: Heuristics and Biases. eds. Daniel Kahneman, Paul Slovic, and Amos Tversky. New York: Cambridge University Press. 
Lord, Charles G., Lee Ross, and Mark R. Lepper. (1979) "Biased Assimilation and Attitude Polarization: The Effects of Prior Theories on Subsequently Considered Evidence." Journal of Personality and Social Psychology 37: 2098-2109.

Lord, Robert G., and Jonathan E. Smith. (1983) “Theoretical, Information Processing, and Situational Factors Affecting Attribution Theory Models of Organization Behavior." Academy management Review 8 (1): 50-60.

Lovallo Dan, and Daniel Kahneman. (2003) “Delusions of Success: How Optimism Undermines Executives' Decisions." Harvard Business Review July.

Malmendier, Ulrike, and Geoffrey Tate. (2005) “CEO Overconfidence and Corporate Investment." The Journal of Finance 60 (6): 2661-2700.

Malmendier, Ulrike, and Geoffrey Tate. (2008) "Who Makes the Acquisitions? CEO Overconfidence and Market's Overreaction." Journal of Financial Economics 89: 20-43.

Markowitz. Harry M. (1952) “The Utility of Wealth." Political Economy 60 (2): 151-58.

McDermott, Ross. (1998) Risk Taking in International Politics: Prospect Theory in American Foreign Policy Ann Arbor: The University of Michigan Press.

Meyer, Werner G. (2014) "The Effect of Optimism Bias on the Decision to Terminate Failing Projects." Project Management Journal 45 (4): 7-20.

Moore Don, and Paul J. Healey (2008) "The Trouble with Overconfidence." Psychological Review 115 (2): 502-517.

Mosteller, Frederich, and Nogee, Philip. (1951) "An Experimental Measurement of Utility." Political Economy 59 (5): 371-404.

Neale, Margaret A., and Max H. Bazerman. (1985). "The Effects of Framing and Negotiation Overconfidence on Bargaining Behaviors and Outcomes." Academy of Management Journal 28 (2): 34-49.

Nisbett, Richard, and Lee Ross. (1980). Human inference: Strategies and Shortcomings of Social Judgment. Englewood Cliffs, NJ: Prentice-Hall.

O’neill, Barry. 2001. "Risk Aversion in International Relations History." International Studies Quarterly 45 (4): 617-640.

Odean, Terrance. (1998). "Volume, Volatility, Price and Profit: When All Traders Are Above Average." Journal of Finance 53 (6): 1887-1934.

Redelmeier, Donald A., and Amos Tversky. 1992. "On the Framing of Multiple Prospects." Psychological Science 3 (3): 191-193.

Russo, Edward J., and Paul J. H. Schoemaker. 1992. "Managing Overconfidence." Sloan Management Review 33 (2): 7-17.

Russo, J. Edward, Kurt A. Carlson, and Margaret G. Meloy. 2006. "Choosing an Inferior Alternative." Psychological Science 17 (10): 899-904.

Schaubroeck, John and Elaine Davis. 1994. "Prospect Theory Predictions When Escalation is not the only Chance to Recover Sunk Costs." Organizational Behavior and Human Decision Processes 57: 59-82

Schmidt, Jeffry B., and Roger J Calantone.1998. "Are Really New Product Development Projects Harder to Shut Down?” Journal of Product Innovation Management 15 (March), 111-23.

Schmidt, Jeffry B., and Roger J. Calantone. 2002. "Escalation of Commitment During New Product Development. Journal of the Academy of Marketing Science 30 (2): 103-118.

Schneider, Sandra L. 1992. "Framing and Conflict: Aspiration Level Contingency, the Status Quo, and Current Theories of Risky Choice.” Journal of Experimental Psychology: Learning, Memory, and Cognition. 18 (5): 1040-1057. 
Schnider, Sandra L., and Lola L. Lopes. 1986. "Reflection in Preferences under Risk: Who and When May Suggest Why” Journal of Experimental Psychology. 12 (4): 535-548.

Schoemaker, Paul J. H. 1982. “The Expected Utility Model: Its Variants, Purposes, Evidence and Limitations.” Journal of Economic Literature 20 (June): 529-563.

Sen, Sanker, and Eric J. Johnson. 1997. "Mere-possession Effects without Possession in Consumer Choice." Journal of Consumer Research 24: 105-117.

Shepperd, James, Wendi Malon, and Kate Sweeny. 2008. "Exploring Causes of the Self-Serving Bias." Social and Personality Psychology Compass 2 (2): 895-908.

Simon, Herbert A. (1955) “A Behavioral Model of Rational Choice." Quarterly Journal of Economics 69 (1): 99-118

Simon, Mark, and Susan M. Houghton. 2003. "The Relationship between Overconfidence and the Introduction of Risky Products: Evidence from a Field Study." Academy of Management Journal 46 (2): 139-149.

Simon, Mark, Susan M. Houghton, and Karl Aquino. (2000). "Cognitive Biases, Risk Perception, and Venture Formation: How Individuals Decide to Start Companies." Journal of Business Venturing 15(2): 113-134.

Skinner Burrhus F. (1974). About Behaviorism. New York: Alfred A. Knopf.

Staw, Barry M. (1976). "Knee-deep in the Big Muddy: A Study of Escalating Commitment of a Chosen Course of Action." Organizational Behavior and Human Decision Processes 16: 22-44.

Stigler, George J. (1950). “The Development of Utility Theory.” Political Economy 58 (4):307-327, Part I

Stigler, George J. (1950) “The Development of Utility Theory.” Political Economy 58 (5): 373-396, Part II.

Taylor, Shelley E. and Jonathon D. Brown. (1988) "Illusion and Well Being: A Psychological Perspective on Mental Health." Psychological Bulletin 103 (2): 193-21.

Taylor, Shelly E. 1991. "Asymmetrical Effects of Positive and Negative Events: The Mobilization-Minimization Hypothesis. Psychological Bulletin 110 (1): 67-85.

Thaler, Richard H., and Eric J. Johnson. 1990. "Gambling with the House Money and Trying to Break Even: The Effects of Prior Outcomes on Risky Choice." Management Science 36 (6): 643-660.

Thaler, Richard. 1980, "Toward a Positive Theory of Consumer Choice." Journal of Economic Behavior and Organization 1: 39-60.

Heukelom, Floris. 2007. Kahneman and Tversky and the origin of behavioral economics (Tinbergen Institute Discussion Papers 07-003/1). Rotterdam, the Netherlands: Tinbergen Institute.

Tversky, Amos, and Daniel Kahneman. (1991) "Loss Aversion in Riskless Choice. A Refrence-Dependent Model." The Quarterly Journal of Economics 106 (4): 1039-161.

Tversky, Amos, and Daniel Kahneman. (1981) The Framing of Decisions and the Psychology of Choice." Science New Series 211 (4481): 453-458.

Tversky, Amos and Daniel Kahneman. 1974. “Judgment under Uncertainty: Heuristics and Biases.” Science New Series 185 (4157): 1124-1131.

Tversky, Amos. 1969. “Intransitivity of Preferences.” Psychological Review 76 (1): 31-48

Tversky, Amos. 1975. "A Critique of Expected Utility Theory: Descriptive and Normative Considerations." Springer 9 (2): 163-173.

Vertzberger, Yaacov Y.I. 2008. "Misperception in International Politics: A Typological Framework for Analysis." International Interactions 9 (3): 207-234 
Vertzberger, Yaacov Y.I. 1995. "Rethinking and Reconceptualizing Risk in Foreign Policy Decision-Making: A Socio-Cognitive Approach.” Political Psychology 16 (2): 347-380.

Vis, Barbara. 2011. Prospect Theory and Political Decision Making. Political Studies Review 9: 334-343.

Vlek, Charles, and Pieter-Jan Stallen. (1981) "Judging Risks and Benefits in the Small and in the Large." Organizational Behavior and Human Performance 28: 235-271.

von Neumann, John, and Oskar Morgenstern. 1944. Theory of Games and Economic Behavior. Princeton: Princeton University Press.

Weber, Martin, and Heiko Zuckel. (2005) "How Do Prior Outcomes Affect Risk Attitude? Comparing Escalation of Commitment and the House-Money Effect." Decision Analysis 2 (1): 30-43.

Weiner, Bernard.(1985) An Attributional Theory of Achievement Motivation and Emotion. Psychological Review 92 (4): 548-573.

Weinstein, Neil D. (1980). "Unrealistic Optimism about Future Life Events." Journal of Personality and Social Psychology 39 (5): 806-820.

Whyte, Glen. (1993). "Escalating Commitment in Individual and Group Decision-Making: A Prospect Theory Approach." Organizational Behavior and Human Decision Processes 54: 430-455. 